\title{
Sugarcane yield loss in the ratoon crop carried over from the plant crop damaged by plant-parasitic nematode in a heavy clay field in Okinawa, J apan
}

\author{
M asanori K awanobe ${ }^{1,2,}$, Naoko M iyamaru ${ }^{1,3}$, K oichi Y oshida ${ }^{1,4}$, Takeshi K awanaka5, \\ Tomonori Fujita ${ }^{1}$ and Koki Toyotal
}

\begin{abstract}
$M$ any field experiments have revealed sugarcane yield loss due to plant-parasitic nematodes, especially in sandy soil, but limited in clay soil. We previously reported a $15 \%$ sugarcane yield reduction in the plant crop in a heavy clay soil due to lesion nematodes suppressing the number of sugarcane tillers in the early growth stage (Kawanobe et al., 2016). Yet, it is unknown whether such early growth inhibition in plant canes will affect the ratoon crop yield in clay soil. The objective of this study was to examine the carry-over effect of yield decline from the plant crop to the ratoon crop in a field with high clay content $(>80 \%)$, in which early growth inhibition, possibly due to lesion nematodes, was observed in a plant crop of sugarcane. Though the Pratylenchus population density remained unchanged among treatments (fosthiazate-treated, $3 \mathrm{~kg}$ and $7.5 \mathrm{~kg} /$ ha at spring planting, and non-treated control), after 5 months (J uly) from the spring planting until the harvest of the ratoon crop, our study showed a $20-25 \%$ higher yield of the ratoon crop in the fosthiazate-treated crop than in the non-treated control. The result in the plant crop carried over to the ratoon crop, and implied that the healthier root grow th of the plant canes achieved by a one-time nematicide application would carry-over to the ratoon crop. The result al so suggested that the number of tillers and cane length observed at 5 months (J uly) in the ratoon crop might adequately ref lect nematode damage and offer a good explanation for the level of the ratoon crop yield. Nematol. Res. 49(1), 1-6. (2019)
\end{abstract}

Key words: carry-over effect, fosthiazate, initial root growth, lesion nematode, Pratylenchus

\section{INTRODUCTION}

Sugarcane (Saccharum species hybrid) has been an important source of income in many tropical and subtropical regions. Sugarcane is a perennial plant and the crop cycle is composed of plant and 2-4 or even more ratoon crops in the preceding years. Y ield of the plant crop is important, yet, farmers are focusing on total yield, including ratoon crop, which contributes directly to farmers' revenue. Many previous studies have reported on sugarcane yield decline due to nematode infestation. Cadet and Spaull (2005) reported very significant yield

${ }^{1}$ Graduate School of Bio-A pplications and Systems Engineering, Tokyo University of A griculture and Technology, Koganei, Tokyo, 184-8588, Japan

${ }^{2}$ A gri-RA N D, Bunkyo-ku, Tokyo, 113-0022, Japan

${ }^{3}$ Okinawa Prefectural A gricultural Research Center, Itoman, Okinawa, 901-0336, Japan

${ }^{4}$ O kinawa A gricultural Technology \& Development Co., Ltd., Itoman, Okinawa, 901-0362, Japan

${ }^{5}$ Okinawa Environmental A nalysis Center Co., Ltd. Ginowan, Okinawa, 901-2215, Japan

*Corresponding author, e-mail: masanori.kawanobe@jp-kawanobe. com loss observed around the globe, including reductions of $10-20 \%$ in Australia, $10-30 \%$ in Brazil, and more than $40 \%$ in South A frica in plant and ratoon crops.

A s indicated by Blair and Stirling (2007), many of previous nematode studies in sugarcane fields were in sandy soil, in which Meloidogyne may be the most important plant-parasitic nematode species (PPN). Bull (1979 and 1981) reported a yield decline of $60 \%$ in plant crop and $20-30 \%$ or more in the ratoon crop in a sandy sugarcane field infested with Pratylenchus. Bond et al. (2000) reported that in 93 sandy soil sugarcane fields with Tylenchorhynchus, Mesocriconema and Pratylenchus, in Louisiana, USA, 13-18\% of yield decline was observed in both plant and ratoon crops. Furthermore, Cadet and Spaull (2003) showed a 30\% yield increase by a nematicide application against Meloidogyne and Pratylenchus, and yields in the ratoon crop were correlated with those in the plant crop in sandy soil in South A frica.

Yet, studies for nematode and sugarcane in clay soil have been limited. Dropkin (1976) reported that the 
populations of PPN might increase or decrease in clay soil depending on the species, and sugarcane yield reduction due to nematodes might be unclear in heavier soil (Spaull and Cadet, 1990). Furthermore, Bond et al. (2000) did not observe a sugarcane yield loss in a field of clay loam soil due to nematodes (including Tylenchorhynchus, M esocriconema, and Pratylenchus), Blair and Stirling (2007) showed a more than $10 \%$ yield loss in both plant and ratoon crops in 14 Pratylenchus (and M eloidogyne in most fields) infested fields with clay soil in Australia by continuous nematicide application throughout both plant and ratoon crops. The clay content of sugarcane fields in Okinawa, Japan, is very high, and the average clay content of sugarcane field soil in $\mathrm{K}$ itadaito Island is $82.5 \pm 8.2 \%$ ( $\mathrm{K}$ injo et al., 2009). O ur previous study (K awanobe et al., 2016) conducted in Okinawa revealed that lesion nematodes may reduce sugarcane yield in spring-plant crops; however, for such high clay content soils, there has been no study performed on the carry-over impact of the nematode infestation on sugarcane yield in plant to that in the successive ratoon crops.

Cadet and Spaull (2005) indicated that the relationship between plant and ratoon crop yield declines due to nematodes might not be clear, as the sugarcane yield in Burkina Faso and Côte d'Ivoire showed nearly $70 \%$ yield loss in plant crop by nematode damage, but only a single digit percentage loss in ratoon crops. Other studies (Bull, 1979 and 1981; Cadet and Spaull, 2003) showed a certain positive relationship between plant and ratoon crops, as shown above, although they were mostly for sandy soil. Although not focused on nematodes, Yoshida et al. (2017) reported a positive relationship between plant and ratoon sugarcane crops in $\mathrm{K}$ itadaito, Okinawa. These previous studies might suggest a carryover effect of sugarcane yield from plant to ratoon crops; however, there has been no report on whether the increase in sugarcane yield by a one-time nematicide application in plant cane would carry-over to the ratoon crop in heavy clay soil.

The objective of this work was to reveal the potential decline in sugarcane yield in the field with a high clay content, and to examine the carry-over effect of the decline in yield from the plant crop to the ratoon crop due to the early sugarcane growth inhibition by nematodes. This work is the first attempt to show that ratoon crop yield decline carried over from the plant crop yield loss is due to nematodes, especially Pratylenchus, in a field with very high ( $80 \%$ or more) clay content. Furthermore, a supplemental pot experiment was conducted to reveal the relationship between lesion nematode density in soil and roots, and the initial growth of sugarcane in soil with a high clay content.

\section{MATERIALS AND METHODS}

The experiment reported in this study successively used the same experimental plots and the methods for soil collection, nematode extraction, nematode count, sugarcane growth, and yield survey as used in K awanobe et al. (2016) in order to monitor the subsequent effect on ratoon cane grow th following the plant cane production.

\section{Experimental plots:}

Fifteen experimental plots $(7 \mathrm{~m} \times 6 \mathrm{~m}$ with 4 rows and a $1 \mathrm{~m}$ buffer zone between the plots; sugarcane variety Cv. F161) were set up in a sugarcane field (pH 4.5; total organic carbon: $10.4 \mathrm{~g} / \mathrm{kg}$; available phosphate: 316 mg / kg; cation exchange capacity: $11.5 \mathrm{cmol} / \mathrm{kg}$, soil collected in 2015) located in K itadaito $\left(25^{\circ} 56^{\prime} \mathrm{N}, 131^{\circ}\right.$ $\left.17^{\prime} \mathrm{E}\right)$, Okinawa, Japan, and sugarcane plants that were originally planted in February, 2014, and harvested in February, 2015. The ratoon canes were grown under the conventional management practice in $\mathrm{K}$ itadaito for 12 months and harvested in February, 2016. A nematicide, fosthiazate (Nemathorin, Ishihara Sangyo K aisha, Ltd., Tokyo, Japan; 1.5\% active ingredient (a.i.)), was applied in granular form and incorporated by tillage at $3 \mathrm{~kg}$ a.i. ( $\times 0.7$ fosthiazate) / ha and $7.5 \mathrm{~kg}$ a.i. ( $\times 1.7$ fosthiazate) / ha, and control (non-treated), in five replicates, just before spring planting (one time). The experimental field was originally infested with economically important insects such as stink bug (C avelerius saccharivorus); yet, it was treated with proper agrochemicals under the conventional management practice

\section{Soil samples:}

At the 5th and 12th months (July 2015 and February 2016, respectively) in the ratoon crop, soil samples were collected at a $0-30 \mathrm{~cm}$ depth with a distance of $10-15 \mathrm{~cm}$ from the base of each of 5 randomly selected sugarcane plants in each of the 15 experimental plots, and were well mixed for the further analysis. The soil in the field was heavy clay (sand $1.3 \%$, silt $11.1 \%$, clay $87.6 \%$, and was collected in September 2016).

\section{Nematodes:}

At the 5th and 12th months of ratoon growth, nematodes were extracted from the soil samples by the B aermann funnel method (room temperature, $72 \mathrm{~h}$ ) using 
$20 \mathrm{~g}$ soil subsamples, in triplicate. Pratylenchus, Helicotylenchus, and other PPN and free-living nematodes ( $F L N)$ were counted under a stereomicroscope (SZX 10, Olympus).

Sugarcane grow th and yield survey:

In the 5th month of the ratoon growth, tillers were counted for the same 2 sugarcane rows used for the yield survey of the spring plants. The culm height at the 5th month of the ratoon growth was recorded as the average of 12 randomly selected canes in the same sections used for counting tillers. At harvest of the ratoon canes, total cane weight, the number of canes, cane diameter, cane length, and sucrose contents were measured.

Lesion nematodes in soil and their penetration into sugarcane roots:

A supplemental pot experiment was conducted to test inhibition of lesion nematodes in soil and their penetration into sugarcane roots in the high clay content soil during the early growth stage of sugarcane. Soil from the same sugarcane field as the field experiment was collected and mixed well. A subsample $(2.8 \mathrm{~kg})$ of the soil was put into a plastic pot (inside diam. $17 \mathrm{~cm}$ and height $15 \mathrm{~cm}$ ) together with $\times 0.7$ or $\times 1.7$ fosthiazate and $1.7 \mathrm{~g}$ of chemical fertilizer (corresponding to N-P-K: 49.3-26.2-49.8 kg / ha). Two single bud setts of sugarcane (cv. Ni29, one of the commonly grown cultivars) were planted in each plastic pot and grown for 7 weeks. Pots without fosthiazate were also prepared as a control. Three replicates were prepared for each treatment. A fter 7 weeks, culm height and the number of fully extended leaves were measured, and each plant was removed from a pot. Roots were carefully washed, cut into $1-2 \mathrm{~cm}$ size, and homogenized in water in a blender for $15 \mathrm{sec}$. Then, the soil in each pot was well mixed. Nematodes were extracted from $1 \mathrm{~g}$ of fresh root and $20 \mathrm{~g}$ of soil subsample by using the Baermann funnel extraction method (three replicates, room temperature, $72 \mathrm{~h}$ ).

\section{Statistical analysis:}

The statistical difference was analyzed by one-way A N OVA using non-log transformed numbers followed by Dunnett's t-test comparing the control and test groups. Repeated measure ANOVA was used to test the hypothesis whether fosthiazate treatment affected the sugarcane grow th and yield for the two consecutive years, followed by Tukey-K ramer's test by using the two year data. Stepwise regression analysis showed the best set of predictors to explain sugarcane yield and to examine potential relationships among the predictors in the field experiment. Statistical analyses were conducted with M icrosoft Excel add-in software Statcel (3rd ed., OM S, Saitama, Japan).

\section{RESULTS}

Nematode population density:

The population densities of Pratylenchus, Helicotylenchus, other PPN, and FLN did not differ significantly among the treatments at the 5th and 12th months of the ratoon crop (Table 1). Other PPN were mostly Tylenchorhynchus and some Hoplolaimus.

\section{Sugarcane growth:}

On a single year basis, sugarcane yield in the ratoon was $20-25 \%$ higher in the $\times 0.7$ and $\times 1.7$ fosthiazate treatments than in the control, although the difference was not significant (Table 2). The number of canes in the $\times 0.7$ fosthiazate treatment, but not the $\times 1.7$, of the ratoon was significantly $(P<0.05)$ higher than that in the control. Cane lengths did not differ among the treatments. Taking both plant and ratoon crops into

Table 1. Pratylenchus, Helicotylenchus, and other plantparasitic and free-living nematode population densities per $20 \mathrm{~g}$ of fresh soil in a field experiment by using the Baermann funnel nematode extraction method. $a, b$

\begin{tabular}{|c|c|c|}
\hline & \multicolumn{2}{|c|}{ Ratoon crop } \\
\hline & 5-month & 12-month \\
\hline \multicolumn{3}{|l|}{ Pratylenchus } \\
\hline Control & $53 \pm 19$ & $35 \pm 25$ \\
\hline$\times 0.7$ fosthiazate & $57 \pm 11$ & $41 \pm 20$ \\
\hline$\times 1.7$ fosthiazate & $58 \pm 17$ & $42 \pm 9$ \\
\hline
\end{tabular}

Helicotylenchus

$\begin{array}{lll}\text { Control } & 36 \pm 10 & 80 \pm 32\end{array}$

$\times 0.7$ fosthiazate $\quad 39 \pm 11 \quad 94 \pm 76$

$\times 1.7$ fosthiazate $\quad 28 \pm 15 \quad 52 \pm 41$

Other Plant-parasitic nematodes

$\begin{array}{lrrrr}\text { Control } & 13 \pm & 10 & 14 \pm & 17 \\ \times 0.7 \text { fosthiazate } & 17 \pm & 4 & 25 \pm & 16 \\ \times 1.7 \text { fosthiazate } & 14 \pm & 7 & 26 \pm & 6\end{array}$

Free-living nematodes

$\begin{array}{lll}\text { Control } & 275 \pm 46 & 361 \pm 61 \\ \times 0.7 \text { fosthiazate } & 223 \pm 106 & 317 \pm 117 \\ \times 1.7 \text { fosthiazate } & 178 \pm 70 & 235 \pm 62\end{array}$

a Experimental plots were treated with $\times 0.7$ fosthiazate $(3 \mathrm{~kg}$ active ingredient (a.i.) / ha) and $\times 1.7$ fosthiazate ( $7.5 \mathrm{~kg}$ a.i. / ha), or non-treated as control in 5 replicates.

${ }^{b}$ Values represent mean nematode density \pm SD of 5 replicates. $\mathrm{N}$ ematode densities of each nematode category did not differ significantly between treated and non-treated plots (Dunnett's test, $\mathrm{P}>0.05)$. 
consideration, repeatedly measured A NOVA for the yield revealed significant main effects (among treatments: $F(2$, $24)=4.66 ; P=0.020$, and between plant and ratoon: $F(1$, $24)=4.69 ; P=0.041)$, and no significant interactions $(F(2,24)=0.12 ; P=0.884)$. The number of canes showed the same trends, i.e., significant main effects (among treatments: $F(2,24)=8.00 ; P=0.002$, and between plant and ratoon: $F(1,24)=27.09 ; P<0.001)$ and no significant interactions $(F(2,24)=0.82 ; P=0.453)$, yet, cane length did not (main effects among treatments: $F(2,24)=0.34$; $P=0.713$, and between plant and ratoon: $F(1,24)=4.89$; $P=0.037$ and interactions: $F(2,24)=0.07 ; P=0.929)$. Then, multiple comparisons using Tukey-K ramer's method showed that both sugarcane yield and the number of canes, but not cane length, were significantly $(P<$ $0.05, n=10$ ) increased in the fosthiazate treatments than in the control (Table 2). Sucrose contents and cane diameters did not differ between treated and non-treated plots in the ratoon canes. With regard to the interim cane growth, the numbers of tillers at the 5th month of the ratoon were significantly $(P<0.05)$ higher in the $\times 1.7$, but not $\times 0.7$, fosthiazate treatment than in the control, while culm height at the 5th month of the ratoon did not differ among treatments (Table 3). Repeated measures ANOVA for the number of tillers at the 5th month for

Table 2. Sugarcane yields, the number of canes, and the cane length at harvest of spring plant and ratoon crops in a field experiment. $a, b$

\begin{tabular}{|c|c|c|c|}
\hline & Spring plant crop $^{c}$ & Ratoon crop & \\
\hline \multicolumn{4}{|c|}{ Sugarcane yield (t / ha) } \\
\hline Control & $47.5 \pm 2.6$ & $40.8 \pm 7.5$ & a \\
\hline$\times 0.7$ fosthiazate & $54.6 \pm 6.0 *$ & $50.8 \pm$ & $b$ \\
\hline$\times 1.7$ fosthiazate & $55.2 \pm 4.7 *$ & $49.1 \pm 9.9$ & $b$ \\
\hline
\end{tabular}

The number of canes (thousand canes / ha)

$\begin{array}{lllll}\text { Control } & 66.2 \pm & 4.4 & 52.2 \pm 6.1 & \text { a } \\ \times 0.7 \text { fosthiazate } & 75.5 \pm & 6.1 * & 66.2 \pm 10.6 * & \text { b } \\ \times 1.7 \text { fosthiazate } & 78.3 \pm & 3.3^{* *} & 60.8 \pm 9.6 & b\end{array}$

Cane length $(\mathrm{cm})$

Control $\quad 186.7 \pm 4.6 \quad 177.3 \pm 12.3 \quad$ a

$\times 0.7$ fosthiazate $189.4 \pm 9.9 \quad 179.5 \pm 9.6 \quad$ a

$\times 1.7$ fosthiazate $189.2 \pm 12.3 \quad 182.7 \pm 12.9 \quad$ a

a Experimental plots were treated with $\times 0.7$ fosthiazate $(3 \mathrm{~kg}$ active ingredient (a.i.) / ha), $\times 1.7$ fosthiazate (7.5 kg a.i. / ha), and non-treated as the control in 5 replicates.

${ }^{b}$ Values represent means \pm SD of 5 replicates. A sterisks indicate significant difference from the control group (Dunnett's test, **: $\mathrm{P}<0.01, *: \mathrm{P}<0.05)$. Different al phabet letters at the right show the significant difference at $P<0.05$ (Tukey$\mathrm{K}$ ramer's test).

${ }^{c} \mathrm{D}$ ata for the spring plant crop were reproduced from K awanobe et al. (2016). both plant and ratoon canes revealed significant main effects (among treatments: $F(2,24)=9.33 ; P=0.001$, and between plant and ratoon: $F(1,24)=140.36$; $P<0.001)$, and no significant interaction $(F(2,24)=0.50 ; P=0.614)$. Then, multiple comparisons using Tukey-K ramer's method showed that the number of tillers at the 5 th month for plant and ratoon canes were significantly $(P<$ $0.05, n=10$ ) higher in the fosthiazate treated canes than in the control (Table 3 ).

Lesion nematodes in soil and their penetration into sugarcane roots (a pot experiment):

The number of lesion nematodes in soil after a 7 -week growth of sugarcane seedlings was significantly $(P<0.01)$ less in the $\times 1.7$ fosthiazate treatment but not in the $\times 0.7$ fosthiazate treatment, than that number in the control (Table 4). That number in roots was significantly $(P<0.01)$ less in the $\times 0.7$ and $\times 1.7$ fosthiazate treatments than in the control (Table 4). The culm height was significantly $(P<0.01)$ greater in the $\times 1.7$ fosthiazate treatment than in the control, but not in the $\times$ 0.7 fosthiazate treatment (Table 4). The numbers of fully extended leaves did not differ among the treatments (Table 4).

Interrelationships among sugarcane yield, its components, and forecasting indicators:

A stepwise regression analysis for sugarcane yield $(y)$, the number of canes $\left(x_{1}\right)$, cane length $\left(x_{2}\right)$, cane

Table 3. The number of tillers and culm height at harvest of spring plant and ratoon crops in a field experiment $a, b$

\begin{tabular}{|c|c|c|c|c|c|}
\hline & $\begin{array}{r}\text { Spring } \\
5-\mathrm{m}\end{array}$ & $\begin{array}{l}\text { lant at } \\
\text { nth }^{c}\end{array}$ & Ratoon at & -month & \\
\hline The number of tiller & rs (thousa & d tillers & / ha) & & \\
\hline Control & $97.0 \pm$ & 2.6 & $74.0 \pm$ & 5.3 & $a$ \\
\hline$\times 0.7$ fosthiazate & $106.1 \pm$ & $2.8 * *$ & $83.0 \pm$ & 7.5 & $b$ \\
\hline$\times 1.7$ fosthiazate & $102.7 \pm$ & $5.4 *$ & $83.5 \pm$ & $4.8^{*}$ & $b$ \\
\hline Culm height $(\mathrm{cm})$ & & & & & \\
\hline Control & $105.2 \pm$ & 5.4 & $129.7 \pm$ & 7.9 & $\mathrm{a}$ \\
\hline$\times 0.7$ fosthiazate & $109.8 \pm$ & 4.9 & $129.5 \pm$ & 9.6 & a \\
\hline$\times 1.7$ fosthiazate & $114.0 \pm$ & $4.6 *$ & $133.2 \pm$ & 8.8 & a \\
\hline
\end{tabular}

a Experimental plots were treated with $\times 0.7$ fosthiazate $(3 \mathrm{~kg}$ active ingredient (a.i.) / ha), $\times 1.7$ fosthiazate (7.5 kg a.i. / ha), and non-treated as control in 5 replicates.

${ }^{\mathrm{b}}$ Values represent means \pm SD of 5 replicates. A sterisks indicate significant difference from the control group (Dunnett's test, $* *: \mathrm{P}<0.01, *: \mathrm{P}<0.05)$. Different al phabet letters at the right shows the significant difference at $P<0.05$ (TukeyK ramer's test).

${ }^{c}$ D ata for spring plant crop were reproduced from Kawanobe et al., 2016 
diameter $\left(\mathrm{x}_{3}\right)$, and sucrose content $\left(\mathrm{x}_{4}\right)$ at the harvest in February, 2016, showed the regression function, $y=$ $0.676 \mathrm{x}_{1}+0.304 \mathrm{x}_{2}-48.149 ; \mathrm{R}^{2}=0.958 ; \mathrm{P}<0.001$. As indicators to forecast sugarcane yield, the number of tillers $\left(x_{5}\right)$ and culm height $\left(x_{6}\right)$ at the 5th month were examined for their ability to explain sugarcane yield $(y)$, and showed an equation, $y=1.057 x_{5}+0.234 x_{6}-68.439$; $\mathrm{R}^{2}=0.784 ; \mathrm{P}<0.001$.

\section{DISCUSSION}

For the entire period of the ratoon, there was no significant difference in each nematode category between the control and fosthiazate treatments. This is consistent with the trend of nematode population density after 5 months ( $\mathrm{uly}$ ) of the spring planting ( $\mathrm{K}$ awanobe et al., 2016). Since fosthiazate has its half-life of 45 days in aerobic soil (US Environmental Protection A gency, 2004), it was considered that there was no nematicidal efficacy remaining during the ratoon period. Therefore, the nematicidal treatment in the prior period did not affect nematode densities of each nematode species in the period of ratoon crop. Since the densities of the major PPN did not differ among the treatments throughout the ratoon crop, the densities might not influence sugarcane growth differently. In spite of showing no difference in the nematode population densities, sugarcane yields in the fosthiazate treated ratoon crop were $20-25 \%$ more than that in the control, and the cumulative yield for the two years was $18-19 \%$ more in the fosthiazate treated crops than in the control. This result of higher yield was supported by a $16-27 \%$ greater number of canes in the ratoon in the fosthiazate treatments than that in the control, and this result was consistent with that of the plant crop (K awanobe et al., 2016). At the 5th month in the ratoon crop, there was no difference in culm height between the fosthiazate treatments and the control; however, the tillering in the fosthiazate treatments overshot the control by ca. $13 \%$. Those resulted in the small difference in cane length and greater difference in the number of canes in the ratoon crop harvest.

The result of this study was consistent with those of Blair and Stirling (2007), which showed higher yields of $15.3 \%$ in the plant crop and $11.6 \%$ in the ratoon crop in 14 P ratylenchus-infested fields with clay contents of $22.3 \%$ $\pm 17.2 \%$ in A ustralia. Our results suggest that higher yields may be expected by nematode control, even in high clay content soils (even more than $80 \%$ ). Blair and Stirling (2007) continuously applied nematicide for the entire experimental periods, including the ratoon crop, while Bull (1979 and 1981) showed that a one-time nematicide application might be sufficient in sandy soil infested by Pratylenchus. These studies were conducted under different conditions for the important aspects of soil texture and nematicide application. O ur study showed that even in very heavy clay soil, a one-time nematicide application may sufficiently increase the sugarcane yield for both plant and ratoon crops. Further study may be essential, yet, this study showed the potential carry-over effect of the nematicide application only at the beginning of the plant crop, as suggested by Donaldson (1987) and Spaull and Cadet (1990). Regarding this point, Cadet and Spaull (2005) discussed the carry-over effect as being the benefit derived from the more extensive root system by lowering the nematode inhibitory effect with a nematicide, such that the ratoon canes may depend on the heal thier roots grown initially.

The pot experiment supported the suppression of lesion nematodes by a nematicide in the initial growth stage of sugarcane. At the end of the initial 7-week growth of sugarcane seedlings in the pot experiment, the numbers of lesion nematodes in the soil were 2 to 5 times more prevalent in the control than in the fosthiazate treatments and the control, yet, those in the roots were 5 to 40 times more prevalent in the control than in the fosthiazate treatments. This suggests potential inhibition of the initial growth of sugarcane, especially through the lesion nematodes' penetration into roots. Together with the results of the 5th month tillering in both plant and

Table 4. The number of Pratylenchus (nematodes / $20 \mathrm{~g}$ soil) in soil and in roots (nematodes / g root), culm height, and the number of fully extended leaves after a 7-week growth of sugarcane in a pot experiment. a, b

\begin{tabular}{|c|c|c|c|c|}
\hline & N ematodes / $20 \mathrm{~g}$ soil & Nematodes / g root & culm height $(\mathrm{cm})$ & $\begin{array}{l}\text { the number of fully } \\
\text { extended leaves }\end{array}$ \\
\hline Control & $48 \pm 4$ & $1,787 \pm 410$ & $24.3 \pm 0.8$ & $5.3 \pm 0.3$ \\
\hline$\times 0.7$ fosthiazate & $25 \pm 17$ & $328 \pm 75^{* *}$ & $24.7 \pm 0.6$ & $5.2 \pm 0.3$ \\
\hline$\times 1.7$ fosthiazate & $10 \pm \quad 3^{* *}$ & $42 \pm 27^{* *}$ & $26.6 \pm 0.3 * *$ & $5.7 \pm 0.3$ \\
\hline
\end{tabular}


ratoon canes, such inhibitory effect may greatly impact the sugarcane yield through the number of canes at harvest. This was supported by a multiple regression analysis.. The number of tillers and culm height in the 5th month (J uly) may have adequately shown the symptoms of nematode damage and be good explanatory factors for the level of sugarcane yield in the ratoon canes. The result was consistent with the one for the spring plant crop (K awanobe et al., 2016).

As a conclusion, this study suggested that the yield increase in the plant crop presented in our previous study may carry-over to the ratoon crop in the soil with high clay content, and implied that the advantage of the early stage root growth during the plant period by a one-time nematicide application would subsequently be reflected in the sugarcane growth in the ratoon crop. The yield increase in the ratoon crop in nematicide treatment may be explained well by the number of tillers and cane length at 5 months (July) in the ratoon crop.

\section{ACK NOW LEDGEMENTS}

We thank the sugarcane farmer in $\mathrm{K}$ itadaito Island who allowed us to use the field and provided the necessary help for this research. We also acknowledge the great help of Kitadaito Seito K.K. and the K itadaito village government with this tough field work. We also thank the voluntary help by M r. Hiromu Senda on our field research.

\section{LITERATURE CITED}

Blair, B. L. and Stirling, G. R. (2007) The role of plantparasitic nematodes in reducing yield of sugarcane in fine-textured soils in Queensland, A ustralia. Australian Journal of Experimental A griculture 47, 620-634.

Bond, J. P., M CGawley, E. C. and Hoy, J. W. (2000) Distribution of plant-parasitic nematodes on sugarcane in Louisiana and efficacy of nematicides. J ournal of Nematology 32, 493-501.

Bull, R. M. (1979) New chemicals for nematode control in the Bundaberg district. In: Proceedings of the A ustralian Society of Sugar Cane Technologists 1, 99-103.

Bull, R. M . (1981) Studies and observations on nematode control in the Bundaberg district. In: Proceedings of the 1981 conference of the A ustralian Society of
Sugar Cane Technologists, 267-274.

Cadet, P. and Spaull, V. W. (2003) Effect of nematodes on the sustained production of sugarcane in South A frica. Field Crops Research 83, 91-100.

Cadet, P. and Spaull, V. W. (2005) Nematode parasites of sugarcane. In: Plant parasitic nematodes in subtropical and tropical agriculture. 2nd edition (LUC, M., Sikora, R. A . and Bridge, J., eds.), CA B International, Wallingford, 645-674.

Donaldson, R. A . (1987) Some aspects related to the use of nematicides on sugarcane in South A frica. In: Proceedings of the annual congress-South A frican Sugar Technologists' A ssociation. 117-120.

Dropkin, V. H. (1976) Nematode parasites of plants, their ecology and the process of infection. In: Physiological Plant Pathology. (Heitefuss, R. and Williams, P. H., eds.), Springer, B erlin, 222-246.

Kawanobe, M., M iyamaru, N., Yoshida, K., Kawanaka, T., and Toyota, K. (2016) A field experiment with nematicide treatment revealed potential sugarcane yield loss caused by plant-parasitic nematodes in Okinawa, Japan. Nematological Research 46, 9-16.

K injo, K., Tokashiki, Y., and K itou, M . (2009) Chemical and mineralogical properties and humic substances of soils cultivated with sugarcane in K ita and Minami Daito Islands, Japan. Tropical Agriculture and Development 2, 80-84. (in Japanese with English summary)

Spaull, V. W. and Cadet, P. (1990) Nematode parasites of sugarcane. In: Plant parasitic nematodes in subtropical and tropical agriculture. (L uc, M ., Sikora, R. A. and Bridge, J., eds.), CA B International, Wallingford, 461-491.

US Environmental Protection A gency (2004) Pesticide Fact Sheet, Office of Pesticide and Toxic Substances (7501C), available online at http:// www3.epa.gov/ pesticides/chem_search/reg_actions/registration/fs_ PC-129022 01-Jan-04.pdf.

Yoshida, K., M iyamaru, N., K awanaka, T., O oshiro, H., Hashimoto, Y. and Toyota, K. (2017) Effect of application of molasses on sugarcane growth, yield, and chemical properties in a red-yellow soil on Kitadaito Island. Japanese J ournal of Soil Science and Plant Nutrition 88, 509-518. (in Japanese with English summary)

Received: M arch 14, 2018 